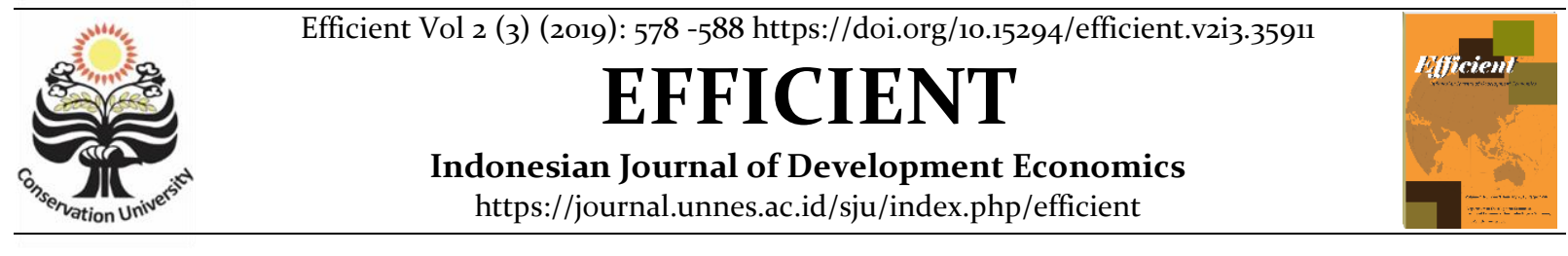

\title{
Increasing Number of Japanese Internship Selection Graduates
}

\author{
Youlia Kardinasari ${ }^{\bowtie}$ \\ Jurusan Ekonomi Pembangunan, Fakultas Ekonomi, Universitas Negeri Semarang
}

Permalink/DOI: https://doi.org/10.15294/efficient.v2i3.35911

Received: Juny 2019 ; Accepted: September 2019 ; Published: December 2019

\begin{abstract}
The internship program to Japan is expected to be able to reduce unemployment due to missmatch between the type and quality of labor produced by the world of education towards the workforce needs in the industrial world. However, the number of graduates of the selection of apprenticeship programs to Japan through government channels is still low, which is below $30 \%$ compared to private channels whose graduation rates can reach $95 \%$. The purpose of this study was to analyze and determine the internal factors and eksternal factors of internship program to Japan and to analyze and find out the strategies that must be done by the government to increase the number of graduates of the selection. This study uses primary and secondary data with descriptive analysis method and SWOT analysis. The results of this study indicate that the internal factor of strength is a particular government program. The weakness of the program is the lack of socialization. eksternal factor Opportunities in the internship program to Japan are to get business capital after an internship to prepare a business. The biggest threat is that selection costs are still quite high. The strategy that can be done to increase the number of graduates of the selection of apprenticeship programs to Japan through government pathway in Central Java is with an aggressive strategy.
\end{abstract}

\section{Keywords: Selection, Internship to Japan, Government Channels}

\begin{abstract}
Abstrak
Program magang ke Jepang diharapkan dapat mengurangi pengangguran karena adanya ketidaksesuaian antara jenis dan kualitas tenaga kerja yang dihasilkan oleh dunia pendidikan terhadap kebutuhan tenaga kerja di dunia industri. Namun, jumlah lulusan yang memilih program pemagangan ke Jepang melalui saluran pemerintah masih rendah, yaitu di bawah 30\% dibandingkan dengan saluran swasta yang tingkat kelulusannya bisa mencapai $95 \%$. Tujuan dari penelitian ini adalah untuk menganalisis dan menentukan faktor internal dan faktor eksternal dari program magang ke Jepang dan untuk menganalisis dan mengetahui strategi yang harus dilakukan oleh pemerintah untuk meningkatkan jumlah lulusan seleksi. Penelitian ini menggunakan data primer dan sekunder dengan metode analisis deskriptif dan analisis SWOT. Hasil penelitian ini menunjukkan bahwa faktor kekuatan internal adalah program pemerintah tertentu. Kelemahan program adalah kurangnya sosialisasi. faktor eksternal Peluang dalam program magang ke Jepang adalah untuk mendapatkan modal bisnis setelah magang untuk mempersiapkan bisnis. Ancaman terbesar adalah biaya seleksi masih cukup tinggi. Strategi yang dapat dilakukan untuk menambah jumlah lulusan dalam pemilihan program magang ke Jepang melalui jalur pemerintah di Jawa Tengah adalah dengan strategi yang agresif.
\end{abstract}

\section{Kata Kunci: Seleksi, Magang ke Jepang, Saluran Pemerintah}

How to Cite: Kardinasari, Y. (2019). Increasing Number of Japanese Internship Selection Graduates. Efficient: Indonesian Journal of Development Economics, 2(3), 278-288. https://doi.org/10.15294/efficient.v2i3.35911

(C) 2019 Semarang State University. All rights reserved

\footnotetext{
Alamat Korespondensi :

Alamat: Gedung L2 Lantai 2 FE Unnes

Kampus Sekaran, Gunungpati, Semarang, 50229

E-mail : youliakardinasari2@gmail.com
} 


\section{INTRODUCTION}

The narrowness of employment in this country to be one factor of high unemployment in Indonesia. Unemployment occurs as a result of economic development that cannot provide employment opportunities that are faster than the increase in the workforce. It is also caused by the competence of job seekers who are not in accordance with the labor market as a result of a mismatch between the type and quality of employment generated by the world of education to the needs of workers in the industrial world..

Labor conditions in Central Java in general showed an improvement, seen from the decline in the number of unemployed in 2013 to 2016. . In 2013 the number of unemployed in Central Java 1,022,789 people. Decreased until 2016 the number of unemployed people in Central Java became 801,330 people. However, unemployment is still high enough that in 2017 increased to 823 938 people are shown in Figure 1. (BPS, 2017).

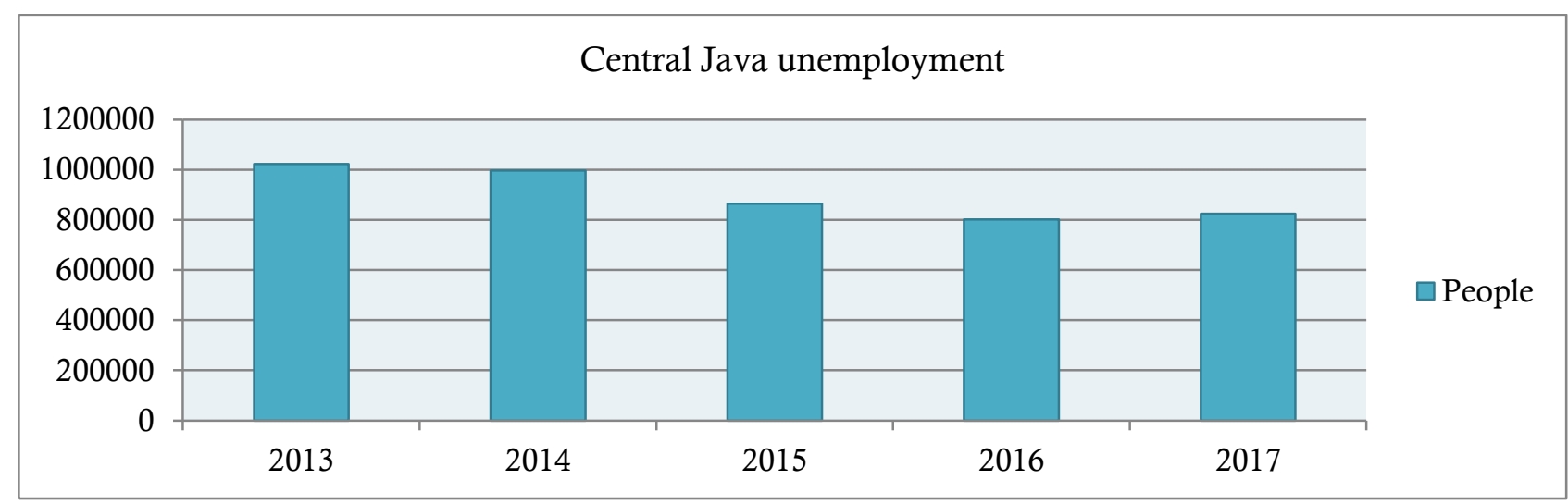

Figure 1. Central Java unemployment (People)

Source : (BPS, 2018)

Reduction of unemployment is one way to build employment in Central Java. Build employment in Central Java aims to reduce unemployment and poverty. The quality of human resources can be a factor in the occurrence of poor people. The quality of human resources can be seen from the quality of life index / human development index (Megawati \& Sebayang, 2018).

Starting from these conditions, the government reduced unemployment by doing the apprenticeship program. According to research Nihaya, Putri, \& Karsinah (2016) Growth and development strategies are intensive actions carried out through the development of workforce competencies to improve the quality of output. This can be done by creating learning resources by designing methods and training referring to Competency Based Training (CBT).

The apprenticeship program is different from TKI (Indonesian Workers) because TKI work purely. In contrast to the internship program, the internship program participants in the destination country practice working with certain qualifications or grades prioritized in accordance with the competencies or job market needs in organizing country. The internship program is the antithesis of the world of education, because the internship is 
$90 \%$ practical and the theory is $10 \%$. The internship program participants are not intended to be a worker but is intended to be entrepreneurs with the skills they have. In addition, the apprentice program participants can only take part in this program once they cannot follow it again (Subianto, 2018).

The apprenticeship program consists of foreign and domestic apprenticeship programs. Overview of the foreign apprenticeship program in Central Java is an internship program to Japan. Apprenticeship program to Japan there are two pathways that government and private lines. The second difference is the path of an apprenticeship program to Japan via private lines, prospective participants after being tested will be given education to prepare themselves to meet Japanese users so that when meeting with Japanese users prospective participants are ready both physically, mentally and in quality.

While the Japanese apprenticeship program using selection, partisipants who made it through the selection stage will leave to Japan. the Japanese apprenticeship program the government gets business capital after returning to Indonesia and the costs incurred for participating in the program are cheaper from the private ones. Thus the Japanese apprenticeship program the government's path was felt to be very effective in reducing unemployment in Central Java.

Participants in the Japanese internship program are dominated by Central Java Province. This is because the character of the Central Javanese community is in accordance with the Japanese cultural diversity (Subianto, 2018). Director Bina Pemagangan Ditjen Bina Lattas Kemnaker RI Drs. Asep Gunawan, M.M. said that Central Java Province is the province with the highest number of applicants for internship programs in Japan. But the program to alleviate unemployment through an internship program to Japan, the government's path is constrained by the low number of graduate selection.

The indicator of graduation from the selection of a Japanese internship program through government channels is determined by IM Japan. Based on data on the number of graduates of the apprenticeship program to Japan, the government route is in Central Java Province. If presented in table 1 , it shows that the percentage of graduates is only $10 \%-30 \%$. The largest percentage in 2013 was $29.4 \%$.

Table 1. Number of Participants Selection and Passing Selection of Participants in Japan Internship Program through Government pathway in Central Java Province 2013-2017

\begin{tabular}{llll}
\hline Year & selection participant (People) & Depart / Pass Selection (PEOPLE) & Percentage (\%) \\
\hline 2013 & 374 & 110 & 29,4 \\
2014 & 273 & 74 & 27,1 \\
2015 & 270 & 45 & 16,6 \\
2016 & 528 & 113 & 21,4 \\
Jumlah & 1445 & 342 & 23,7
\end{tabular}

Source: Disnakertrans, processed 2018 
The number of participants the Internship program to Japan through private pathway is different from the government's path. Compared with the government's path which has a large number of applicants but the selection rate of graduation is still low the number of participants in the internship program to Japan through the private sector is more. This is shown in table 2 that in 2013 the number of participants amounted to 164 then continued to increase until 2016 which reached 504 people.

Table 2. The number of Participants the Internship Program to Japan Private pathway in Central Java Province 2013-2017

\begin{tabular}{lllll}
\hline Year & $\begin{array}{l}\text { Number } \\
\text { (People) }\end{array}$ & & \\
\hline 2013 & 164 & & \\
2014 & 221 & & \\
2015 & 404 & & \\
2016 & 504 & & \\
Total & 1293 & & \\
\hline
\end{tabular}

Source : (Pemagangan, 2018)

Based on the description that the apprenticeship program to Japan through the government pathway has great benefits but the number of graduate selection a lower compared to private channels, The purpose of this study was to analyze and determine the internal factors and eksternal factors of internship program to Japan and to analyze and find out the strategies that must be done by the government to increase the number of graduates of the selection.

\section{METHOD}

This research is a descriptive quantitative study used to describe the motivating factor and inhibiting factors of internship program to Japan through government path in Central Java. Use SWOT analysis to systematically analyze data to formulate strategies. Environmental analysis is needed to identify various factors, including strengths, weaknesses, opportunities, and threats. The results of the analysis can be used to conduct internal evaluations (Internal Factors Evaluation= IFE) and external evaluation (External Factors Evaluation = EFE) (Pujiati, Nihaya, \& Setiyani, 2016). So that the government strategy can be determined to increase the number of graduate in participating in the selection of internship programs to Japan through the government path in Central Java.

Sources of data obtained through primary data and secondary data. Primary data is obtained through questionnaires distributed and filled out by respondents, direct observation and interviews. Secondary data comes from reports on the implementation of an internship program to Japan by the Central Java Provincial Manpower and Transmigration Office from 2013 to 2017, Journal, Regulations on apprenticeship, and other literature on apprenticeship programs.

The population of this study were participants in the apprenticeship program in Japan in 2017 phase II who participated in the selection total of 720 people and the government as the executor and other related parties as many as 5 people. The sample used as respondents in this study were 73 people consisting of government and related parties as many as 5 people and participants passed the pre-departure training selection as many as 68 people using the Slovin formula. Determination number of samples in this study using Probabilyty Sampling types Simple 
Random Sampling conducted randomly without regard to strata that exist in the population.

\section{RESULTS AND DISCUSSION}

The apprenticeship program to Japan through the government in Central Java has existed since 1993. The program was implemented with the aim of reducing missmatch between the world of education and the world of industry so as to reduce unemployment and improve the welfare of the workforce. In this study of 68 respondents 43 people were unemployed, usually those who registered for the program were unemployed because their employment contract had expired. This type of unemployment is usually classified as open unemployment. 19 people intentionally quit their jobs because they felt the internship program in Japan was good for their future and 6 people were odd jobs such as helping parents, making bricks, and construction workers whose projects were finished. This type of labor usually enters the underemployed group.

The selection process of an internship program to Japan through government path has 7 stages, namely the initial test in the form of a math test, physical test, physical endurance test, and interview test conducted at the Manpower and Transmigration Office of Central Java Province. After the four stages of the selection were completed, the participants conducted Medical Check Up (MCU) conducted at the hospital designated by the ministry, participants had to prepare Rp. 1.050.000,00 to do the MCU.

The next stage is the education stage, namely the Japanese language test in the province, this Japanese test provides an opportunity for participants to do remedies 3 times. After being declared to have passed the Japanese language test the participants conduct pre-departure training in the area for 2 months and 10 days at a cost of Rp. 3,700,00o for the cost of food and shelter during the training. Participants who are already at this stage already have their destination company occupied during their stay in Japan. After the participants carry out the pre-departure training, participants usually return to their homes for 1 month to do homework. Before leaving for the pre-departure training phase two the homework will be checked first, after which the participants will depart to Lembang at a personal fee. Participants conducted a second phase of training for 2 months which was the stage of strengthening mental, attitude, language and culture of Japan. At this stage the cost of the second phase of training is borne by the company that will be occupied by the participants.

Table 3 shows that the selection stages that most aborted participants were at the mathematics test stage as many as 185 people, physical endurance test as many as 180 people, and physical test as many as 63 people. This is because participants who register lack preparation and training so that at the time of selection they are unable to meet existing graduation standards. This is due to lack of program socialization.

SWOT analysis is the identification of various factors systematically to formulate a corporate strategy, according to Rangkuti (2006) SWOT stands for internal environment strengths and Weaknesses and external environments opportunities and Threats faced 
in the business world. Analysis is based on logic that can maximize strengths and opportunities, but simultaneously can minimize weaknesses and threats. The strategic decision making process is always related to the development, mission, goals, strategies, and company policies. Thus the strategic planner must analyze the company's strategic factors (strengths, weaknesses, opportunities and threats) in the current conditions. In formulating a strategy to increase the number graduate of selection the Internship program to Japan, researchers conducted a SWOT analysis by first identifying factors of strengths, weaknesses, opportunities and threats.

Table 3. Tabulation of Results of the Implementation of the Internship Program to Japan Through the Government Pathway in Central Java 2017 Phase II (People)

\begin{tabular}{lllll}
\hline NO & KEGIATAN & PARTISIPANT & NOT GRADUATE & GRADUATE \\
\hline $\mathbf{1}$ & MATH TEST & 720 & 185 & 535 \\
$\mathbf{2}$ & PHYSICAL TEST & 535 & 63 & 472 \\
3 & PHYSICAL ENDURANCE TEST & 472 & 180 & $\mathbf{2 9 2}$ \\
4 & INTERVIEW TEST & 292 & 20 & $\mathbf{2 7 2}$ \\
5 & MCU & 272 & 27 & $\mathbf{2 4 5}$ \\
6 & JAPANESE LANGUAGE TEST & $\mathbf{2 4 5}$ & $\mathbf{2 3}$ & $\mathbf{2 2 2}$ \\
7 & PRE DEPARTURE & $\mathbf{2 2 2}$ & $\mathbf{2 1 0}$ \\
TOTAL & - & 510 & - \\
\hline
\end{tabular}

Sumber : (Disnakertrans, 2018)

Weighting in strategic factors to increase the number graduate of selection the Internship program to Japan $=\mathrm{mx} / \mathrm{mt}, \mathrm{mx}$ : mean from factor $\mathrm{x}$ dan $\mathrm{mt}$ : mean total internal strategic factors. While the rating goal is to provide a scale ranging from 4 to 1 based on the influence of these factors on the internship program to Japan through the government in Central Java. The total value in the table shows how the internship program in Japan reacts to its internal strategic factors.

Internal strategy factors that consist of strengths and weaknesses. The highest strength factor with weighting is that this program is a special government program that scores 0.47 . This apprenticeship program to
Japan is special because there are many benefits and facilities obtained by participants during the program. This internship program to Japan is a collaboration between the Japanese government and the Indonesian government. Participants who left for Japan got the facilities provided by IM Japan in the form of accommodation and transportation. Get pocket money for 3 years in Japan. Get protection and insurance except toothache, congenital pain suffered before arriving in Japan. The same protection of labor as Japanese workers. And get an independent business capital allowance for participants who complete the program for 3 years properly. 
Table 4. Internal Factor Matrix and External Factor Matrix of Internship Program to Japan

\begin{tabular}{|c|c|}
\hline Internal Factor & External Factor \\
\hline Strenght & Opportunity \\
\hline Age of participants is still productive & Obtaining post-apprenticeship business \\
\hline Big pocket money & capital for provision of starting a \\
\hline Not limited to participants who qualify & business \\
\hline Special government programs & There is an international certificate \\
\hline Weakness & The existence of LPK (Work Training \\
\hline Relatively difficult selection & Institution) as a supporting partner \\
\hline Less socialization & Cooperation between LPK and the \\
\hline Participants lack training and preparation & Government \\
\hline Mental and participant discipline is still & Delivery of participants in many fields \\
\hline lacking & Facilities and infrastructure that can be \\
\hline lack of support Kab/Kota & improved \\
\hline Limited funds & Threat \\
\hline \multirow[t]{4}{*}{ The waiting time is relatively long } & $\begin{array}{l}\text { Children who cannot complete the } \\
\text { program will get sanctions }\end{array}$ \\
\hline & $\begin{array}{l}\text { Business capital obtained is not used for } \\
\text { business }\end{array}$ \\
\hline & Going home is unemployed again \\
\hline & Selection costs are still quite high \\
\hline
\end{tabular}

Source: Research Results Processed

The weakness of an internship program to Japan through government channels in Central Java is that there is less socialization that gets a weighting value of 0.21 . The main problem with the Japanese apprenticeship program is that the socialization carried out by the provincial government has not been evenly distributed to all regencies / cities in Central
Java. In addition, cooperation between the provincial government and the district / city government is also felt to be lacking. If the information received by the community is not in full, it will make the prospective participants less prepared so that when the selection will be terminated because to be able to pass a series 
of selection of Japanese internship programs must be balanced with training and hard work.

Table 5 • Internal Factor Evaluation (IFE)

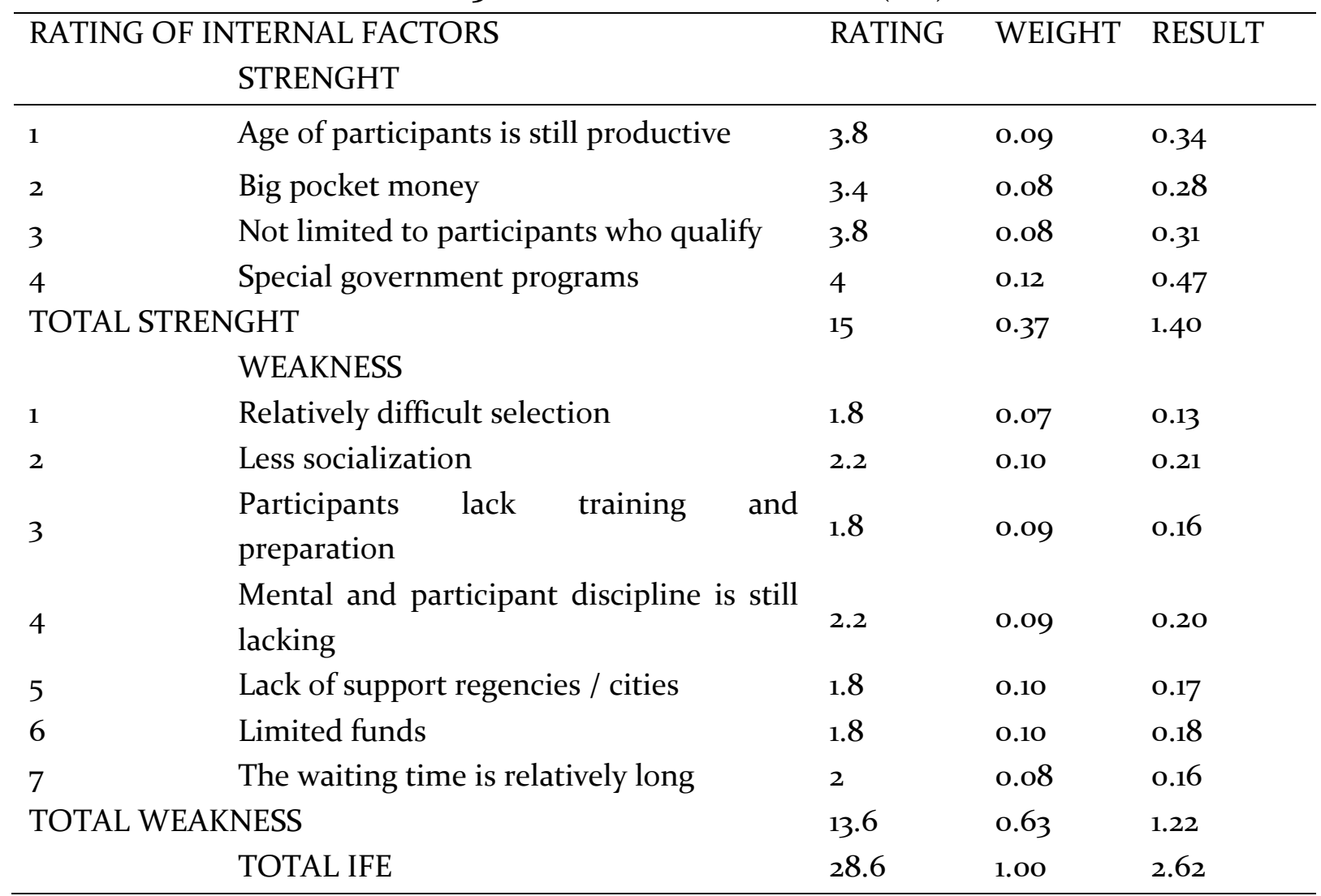

Source: Research Results Processed

External factors which consist of opportunities and threats. The opportunity factor in the apprenticeship program to Japan is obtaining business capital after an internship to prepare a business that gets a score of 0.44 . The requirement to obtain this capital is to be able to complete an internship program for 3 years. This capital is expected to be used as the initial capital for businesses so that they are able to apply the knowledge acquired while in Japan and to open a business field at least for themselves or other people in their area. The type of business obtained from capital is not determined because regions have different characteristics such as differences in natural resources, differences in demographic conditions, centralized economic activities in a region, lack of smooth mobility of goods and services, and also from human resources (Wahyuni \& Pujiati, 2016 ) So it is expected that the type of business that will be established by the participants is adjusted to the characteristics of each region.

The threat factor in the apprenticeship program to Japan through the government route in Central Java, which has the highest weighting value is the selection cost which is still quite high with a weighting value of $\mathbf{0 . 2 2}$. This is because the costs that must be prepared by participants are in the range of 10 million and above. So it is feared that participants with economically disadvantaged backgrounds 
cannot afford to take part in this selection series.

Table 6. External Factor Evaluation (EFE)

\begin{tabular}{|c|c|c|c|c|}
\hline \multicolumn{2}{|c|}{ RATING OF EXTERNAL FACTORS } & \multirow[t]{2}{*}{ RATING } & \multirow[t]{2}{*}{ WEIGHT } & \multirow[t]{2}{*}{ RESULT } \\
\hline & OPPORTUNITY & & & \\
\hline 1 & $\begin{array}{l}\text { Obtaining post-apprenticeship business capital } \\
\text { for provision of starting a business }\end{array}$ & $3 \cdot 4$ & 0.13 & 0.44 \\
\hline 2 & There is an international certificate & 3.6 & 0.12 & 0.43 \\
\hline 3 & The existence of LPK as a supporting partner & 3.2 & 0.10 & 0.33 \\
\hline 4 & Cooperation between LPK and the Government & 3.2 & 0.11 & 0.36 \\
\hline 5 & Delivery of participants in many fields & 3.4 & 0.09 & 0.31 \\
\hline 6 & $\begin{array}{l}\text { Facilities and infrastructure that can be } \\
\text { improved }\end{array}$ & $3 \cdot 4$ & 0.13 & 0.43 \\
\hline \multicolumn{2}{|c|}{ TOTAL OPPORTUNITY } & 20.2 & 0.68 & 2.31 \\
\hline \multicolumn{5}{|c|}{ THREAT } \\
\hline 1 & $\begin{array}{l}\text { Children who cannot complete the program } \\
\text { will get sanctions }\end{array}$ & 1.8 & 0.07 & 0.12 \\
\hline 2 & $\begin{array}{l}\text { Business capital obtained is not used for } \\
\text { business }\end{array}$ & 3 & 0.07 & 0.21 \\
\hline 3 & Going home is unemployed again & 3 & 0.07 & 0.21 \\
\hline 4 & Selection costs are still quite high & 2 & 0.11 & 0.22 \\
\hline \multicolumn{2}{|c|}{ TOTAL THREAT } & 9.8 & 0.32 & 0.76 \\
\hline & TOTAL EFE & 30 & 1.00 & 3.07 \\
\hline
\end{tabular}

Source: Research Results Processed

From the results of the SWOT calculation, it can be seen that the apprenticeship program to Japan through the government in Central Java has a greater strength than the existing weaknesses and has a greater chance than the threat with the following values:

Internal Factors Strength - Weakness $=1,40-$ $1,22=0,18$

External Opportunity Factors - Threats = 2,31-0,76=1,55

Based on this value, the position of the internship program in Japan feels in the first quadrant that supports an aggressive strategy to increase the number of graduates of the selection as shown in figure 3.

Strategy for Increasing the Number of Graduates Selection of Internship Programs to Japan Through Government Pathways in Central Java is to be carried out with an aggressive strategy where this strategy is focused on solving all obstacles faced by utilizing the strengths and opportunities of the internship program to Japan. Strategies that can be offered include (a) utilizing LPK to increase participants who pass; (b) increase the motivation of participants; (c) conduct screening when participants want to register 
for this internship program; (d) increasing the support of districts / cities from participants by

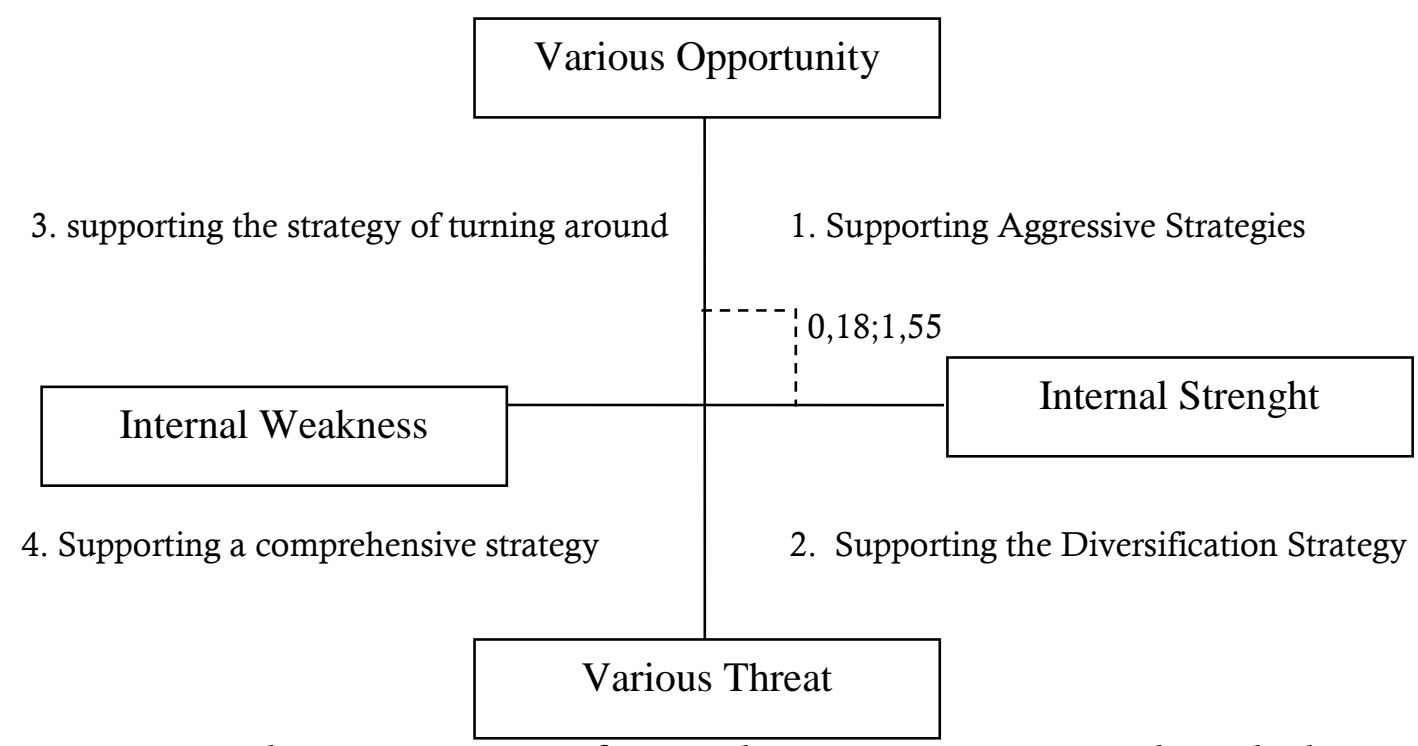

Figure 3. Grand Strategy Matrix of Internship Program to Japan Through the Government in Central Java

\section{CONCLUSION}

The internal strength factor strategy is the most important factor with the highest weighting of the apprenticeship program to Japan, the government's path in Central Java is this program is a special government program. The internal weakness factor of the apprenticeship program to Japan through the government path in Central Java, the most important is lack of socialization. The external opportunity strategy factor in the apprenticeship program to Japan is obtaining business capital after an internship to prepare for starting a business. The external threat factor in the apprenticeship program to Japan through the government path in Central Java, which has the highest weighting value, is the selection cost which is still quite high. The strategy to increase the number of graduates of apprenticeship selection programs to Japan through government channels in Central Java is to be carried out with an aggressive strategy in which this strategy is focused on utilizing the strengths and opportunities of internship programs to Japan through the Government in Central Java.

Based on the results of the analysis and discussion above, the suggestions that can be given are: (1) The government can increase the motivation of participants by giving direction. This can be done before participants carry out a series of selections. (2) Utilizing LPK by informing that participants who can qualify for selection are usually participants who participate in LPK, that one of the participants' strategies to qualify is to enter LPK, the government can also inform and provide a good description of LPK in the area of origin of participants participants did not hesitate to follow. (3) The Central Java Provincial Government needs to increase the participation of the district / city government in implementing this program. The assistance can be in the form of physical assistance such 
as providing training in each district / city before the selection is carried out. (4) The government is expected to carry out preliminary checks to the registrants to ascertain whether the participants have been qualified so that the registrants are truly qualified.

\section{REFERENCES}

BPS, 2017. Tingkat Pengangguran Terbuka. [Online] Available

at: https://jateng.bps.go.id/linkTableDinamis/view/i d/34 [Accessed 27 November 2017].

Disnakertrans, 2017. Laporan Program Magang Jepang, Semarang: s.n.

Disnakertrans, 2018. Laporan Penyelenggaraan Program Magang Ke Jepang Tahap II 2017.

Kemnakertans, 2010. Himpunan Peraturan Perundangundangan Bidang Pemagangan. Jakarta: Kemnakertrans.

Megawati, E. \& Sebayang, L. K. B., 2018. Determinan Kemiskinan di Provinsi Jawa Tengah Tahun 2011-
2014. conomics Development Analysis Journal, Volume 7, pp. 235-242.

Nihaya, D. M., Putri, P. I. \& Karsinah, 2016. Labor Development Strategy in the Bag Industry. Economic Journal of Emerging Markets, Volume 8, pp. $73-84$.

Pemagangan, 2018. Kementrian Ketebagakerjaan Direktorat Jenderal Pembinaan Pelatihan Dan Produktifitas. [Online] Available at: www.pwmagangan.com/database/index.php\# [Accessed 27 Juni 2018].

Pujiati, A., Nihaya, D. M. \& Setiyani, R., 2016. Rambutan Commodity Development Strategy as Regional Potential Product. JEJAK : Jurnal Ekonomi Dan Kebijakan, Volume 9, pp. 50-61.

Rangkuti, F., 2006. Analsis SWOT : Teknik Membelah Kasus Bisnis. Jakarta: PT. Gramedia Pustaka Utama.

Subianto, 2018. Magang Ke Jepang Jalur Pemerintah di Jawa Tengah [Interview] 2018.

Wahyuni, L. E. \& Pujiati, A., 2016. Disparitas Pembangunan Wilayah Kabupaten/ Kota di Provinsi Jawa Tengah. Economics Development Analysis Journal, Volume 5, pp. 296-305. 